\title{
Weed Control in Maize-Cowpea Intercropping System Related to Environmental Resources Consumption
}

\author{
Hamdollah ESKANDARI ${ }^{1}$, Kamyar KAZEMI $^{2}$ \\ ${ }^{1}$ University of Payame Noor, Department of Agriculture, Omidieh Branch, Omidieh, Iran; ehamdollah@gmail.com \\ ${ }^{2}$ University of Payame Noor, Department of Agriculture, Shadegan Branch, Shadegan, Iran
}

\begin{abstract}
A field experiment was carried out in Ramhormoz, Iran during the 2008-2009 growing season to investigate the effects of different planting pattern of intercropping on environmental resource consumption and weed biomass. A randomized complete block design (RCBD) with three replications was employed to compare the treatments. Treatments included maize sole crop (M), cow pea sole crop $(\mathrm{C})$, within row intercropping $\left(\mathrm{I}_{1}\right)$, row intercropping $\left(\mathrm{I}_{2}\right)$ and mix cropping $\left(\mathrm{I}_{3}\right)$. The density of intercropping was according to replacement design (one maize replaced by three cow pea plants). The results showed that environmental resource consumption was significantly $(\mathrm{P} \leq 0.05)$ affected by cropping system, where PAR interception, moisture and nutrients uptake were higher in intercropping systems compared to sole crop systems. Regarding to weed control, intercrops were more effective than sole crops and it was related to lower availability of environmental resources for weeds in intercropping systems.
\end{abstract}

Keywords: cereal, legume, nutrient uptake, photosynthetically active radiation

\section{Introduction}

Weed, a plant growing where it is not desirable, declines yield production and quality of crop plants and leads to higher cost in food production (Pandya et al., 2005). Therefore, weed control is one of the most important aspects of crop production in agricultural systems. Although appropriately selected herbicides may perform an important role in weed infestation reduction, increasing weeds resistance to herbicides, high cost and, especially, negative effects of herbicides on environment have increased the need of non-chemical weed control in agroecosystems (Augustin, 2003; Kropff, 1993; Spliid et al., 2004).

Intercropping is an agricultural practice which can be used for decreasing the dependency on chemical herbicides in weed control (Banik et al., 2006) and defined as the growth of two or more crop species simultaneously in the same field during a growing season (Ofori and Stern, 1987). Intercropping generate beneficial biological interactions between crops, increasing grain yield and stability, more efficient using available resources and reducing weed pressure (Jenson et al., 2006; Kadziuliene et al., 2009). Many authors indicate the limiting effect of intercropping on the number and biomass of weeds (Amanullah et al., 2006; Banik et al., 2006; Carruthers et al., 1998; Gharineh and Moosavi, 2010; Poggio, 2005).

There are two possible reasons for the reduction of weeds biomass in intercropping systems. Some intercrop species release allelopathic compounds which limit the occurrence of weed (Oleszek, 1994; Wanic et al., 2004). The another one is: intercropping provides an efficient utiliza- tion of environmental resources (Eskandari and Ghanbari, 2009). Thus, the growth of weeds, depending on the availability of environmental resources, is decreased. The main principle of better resource use in intercropping is that if crops differ in the way they utilize environmental resources when grown together, they can complement each other and make better combined use of resources than when they grown separately (Ghanbari-Bonjar, 2000). Weed suppression in intercropping through more efficient use of environmental resources by component crops has been reported (Liebman and Dyck, 1993; Mashingaizde et al., 2000; Mashingaizde, 2004; Poggio, 2005).

The aim of the present study was to quantify the effect of intercropping on weed suppression by evaluating the amount of environmental resources consumption including, photosynthetically active radiation (PAR), moisture and nutrients.

\section{Materials and methods}

A field experiment was conducted during the 20082009 growing season on a field in Ramhormoz, Khuzestan, Iran $\left(46^{\circ} 36^{\prime} \mathrm{N}, 31^{\circ} 16^{\prime} \mathrm{E}\right.$, altitude $150 \mathrm{~m}$ above sea level). The experiment was established in a silt loam soil with $\mathrm{pH}$ 7.1. The previous crop was winter wheat which was harvested in May 18, 2009. After that, wheat straw was removed from field.

Five treatments (two monocultures and three mixtures of maize and cow pea) were compared in a randomized complete block design (RCBD) in three replications, including sole cow pea $(\mathrm{C})$, sole maize $(\mathrm{M})$, alternate-row in- 
58

tercropping $\left(\mathrm{I}_{1}\right)$, within-row intercropping $\left(\mathrm{I}_{2}\right)$ and mixed intercropping $\left(\mathrm{I}_{3}\right)$.

The intercrop composition was based on the replacement design (Snaydon, 1991), in which one maize was replaced by three cowpea plants. Total population of intercrop components were half of their sole crops. The plots size was $12 \mathrm{~m}^{2}$ consist of six rows of $2 \mathrm{~m}$ long. The rows located $50 \mathrm{~cm}$ apart. Treatments were separated by a $2 \mathrm{~m}$ buffer zone. The site of experiment was ploughed to 0.2-0.3 m depth after the removal of winter wheat straw, followed by harrowing prior to drilling the trial. All plots were fertilized with the same amount of fertilizer before sowing, containing $70 \mathrm{~kg}$ of $\mathrm{N} \mathrm{ha}^{-1}, 70 \mathrm{~kg} \mathrm{P}_{2} \mathrm{O}_{5} \mathrm{ha}^{-1}$ and 70 $\mathrm{kg}$ of $\mathrm{K}_{2} \mathrm{O} \mathrm{ha}{ }^{-1}$. Maize and cowpea were sown to a depth of approximately 7 and $5 \mathrm{~cm}$ respectively by hand in July 26 , 2009. Seed rates of 10 and 38 seeds of maize and cowpea, respectively, per $\mathrm{m}^{2}$ were sown to allow for thinning down to an approximate plant population of 6.7 and 20 plants per $\mathrm{m}^{2}$.

Photosynthetically active radiation (PAR) was measured two times during the growing season ( 55 and 70 days after sowing) between 12-14 hours on occasions. A Sun fleck ceptometer (model SF-80T) was used to measure above the plant canopy and the soil surface at 5 randomly selected locations within each plot. Mean values for each plot were then used to calculate the percentage of PAR intercepted by plant canopy (Ghanbai-Bonja, 2000). The soil water balance was expected to be influenced by different cropping systems. Soil water content at $0-0.25 \mathrm{~m}$ depth was determined on two occasions (55 and 70 days after sowing) during the growing season. Soil samples were taken from three locations within each plot and a well mixed sample was used to determine soil moisture content by gravimetric measurement. Soil temperature was also recorded at a depth of $0-10 \mathrm{~cm}$ below the surface on two occasions in all plots, using a soil thermometer.

All plants of each plot were harvested simultaneously in a $1 \mathrm{~m}^{2}$ area of each plot in October 25, 2009 and separated into maize, cow pea and weeds. Weeds were dried in the oven at $70^{\circ} \mathrm{C}$ for $48 \mathrm{~h}$ and weighed to record dry matter yield. Nutrients uptake by intercrop components were determined by measuring the $\mathrm{Ca}, \mathrm{Mg}, \mathrm{K}$ and $\mathrm{P}$ amount of maize and cow pea tissues using atomic absorption spectrophotometer (model AA100).

The analysis of variance of the data was carried out, using MSTATC software. Treatment mean differences were separated by the least significant difference (LSD) test at 0.05 probability level.

\section{Results and discussion}

Percentage of PAR interception was significantly $(\mathrm{P} \leq$ 0.05 ) affected by cropping system (Tab. 1). The mean of PAR interception averaged over sampling dates by intercrop treatments and sole cropped cowpea were significantly $(\mathrm{P} \leq 0.05)$ higher than that of sole cropped maize. The mean percentage of PAR interception for the intercrop treatments and cowpea sole crop was similar at 55 days after sowing (DAS) and higher for intercrop treatment at 70 DAS (Tab. 1).

Soil temperature was significantly $(\mathrm{P} \leq 0.05)$ affected by cropping systems. At 55 DAS, the soil temperature for intercrop treatments and cowpea sole crop was significantly lower than that of sole cropped maize (Tab. 1). At 70 DAS, soil temperature under intercrop treatments was significantly $(\mathrm{P} \leq 0.05)$ lower than for maize and cow pea sole crops.

The moisture content of soil, determined by gravimetric method, was significantly $(P \leq 0.05)$ influenced by cropping system (Tab. 1). Moisture content of soil in sole cropped wheat at two sampling dates was higher than for intercrop treatments and cowpea sole crop. However, there was no significant difference between maize and cowpea sole cropped at 55 DAS.

Different in vertical arrangement of foliage and canopy architecture of intercrop components, may lead to more PAR interception by intercropping compared with sole crops (Keating and Carberry, 1993). More PAR interception by different intercropping systems has been reported (Chand, 1997; Ghanbari-Bonjar, 2000; Midmore et al., 1988). High light interception by intercrops caused higher shading and, therefore, lowers soil temperature, which agrees with the finding of Harris and Natarajan (1987) who suggested that the micro climate within the canopy

Tab. 1. Effect of different cropping system on PAR interception, soil temperature and soil moisture content

\begin{tabular}{ccccccc}
\hline \multirow{2}{*}{ Cropping system } & \multicolumn{2}{c}{ PAR interception $(\%)$} & \multicolumn{2}{c}{ Soil temperature $\left({ }^{\circ} \mathrm{C}\right)$} & \multicolumn{3}{c}{ Soil moisture content $(\%)$} \\
\cline { 2 - 7 } & 55 DAS & 70 DAS & 55 DAS & 70 DAS & 55 DAS & 70 DAS \\
\hline C & $63.8 \mathrm{a}$ & $71.3 \mathrm{~b}$ & $28.0 \mathrm{a}$ & $28.9 \mathrm{~b}$ & $15.9 \mathrm{~b}$ & $71.3 \mathrm{~b}$ \\
$\mathrm{I}_{1}$ & $69.4 \mathrm{a}$ & $98.2 \mathrm{a}$ & $28.3 \mathrm{a}$ & $27.6 \mathrm{a}$ & $9.4 \mathrm{a}$ & $98.2 \mathrm{a}$ \\
$\mathrm{I}_{2}$ & $66.4 \mathrm{a}$ & $97.5 \mathrm{a}$ & $27.9 \mathrm{a}$ & $27.5 \mathrm{a}$ & $11.5 \mathrm{a}$ & $97.5 \mathrm{a}$ \\
$\mathrm{I}_{3}$ & $64.2 \mathrm{a}$ & $97.1 \mathrm{a}$ & $27.1 \mathrm{a}$ & $26.5 \mathrm{a}$ & $12.2 \mathrm{a}$ & $97.1 \mathrm{a}$ \\
$\mathrm{M}$ & $32.3 \mathrm{~b}$ & $62.1 \mathrm{c}$ & $30.5 \mathrm{~b}$ & $30.0 \mathrm{~b}$ & $16.8 \mathrm{~b}$ & $62.1 \mathrm{c}$ \\
\hline LSD at $0.05 \%$ & 7.30 & 2.90 & 1.39 & 1.21 & 3.50 & 2.90 \\
\hline
\end{tabular}

Different letters in each column indicate significance at $\mathrm{P} \leq 0.05$; C: sole cow pea; $\mathrm{I}_{1}$ : alternate-row intercrop; $\mathrm{I}_{2}$ : within-row intercrop; $\mathrm{I}_{3}$ : mixed intercrop; M: sole maize; DAS: days after sowing; PAR: Photosynthetically active radiation 
of cropping systems were altered, so that shading reduced canopy temperature. Thus, it seems that percent of light interception by canopies would be a major factor affecting soil temperature. Intercropping may be more efficient at exploiting a larger total soil volume if component crops have different rooting habits, especially depth of rooting (Ahlawat et al., 1985). Lower soil moisture content in intercrops treatments compared to sole crop could not be due to higher evaporation from the soil surface, because soil temperatures under intercrops were lower than sole crops (Tab. 1). One explanation for more water extraction with intercrops could be as a result of more soil exploration by root system of intercrop, resulting in a drier soil profile compared to that for sole crop.

Nutrients $(\mathrm{Ca}, \mathrm{Mg}, \mathrm{K}$ and $\mathrm{P}$ ) uptake were significantly $(P \leq 0.05)$ affected by cropping system (Tab. 2), where intercropping systems absorb more $\mathrm{Ca}, \mathrm{Mg}$ and $\mathrm{P}$ compared to sole crop systems. There was no significant difference between intercrops for nutrients uptake. There was no significant difference between intercrops and cow pea sole crop for K uptake (Tab. 2).

Tab. 2. Effect of different cropping system on nutrient uptake $\left(\mathrm{kg} \mathrm{ha}^{-1}\right)$

\begin{tabular}{ccccc}
\hline \multirow{2}{*}{$\begin{array}{c}\text { Cropping } \\
\text { system }\end{array}$} & \multicolumn{4}{c}{ Nutrient uptake } \\
\cline { 2 - 5 } & $\mathrm{Ca}$ & $\mathrm{Mg}$ & $\mathrm{K}$ & $\mathrm{P}$ \\
\hline $\mathrm{C}$ & $24.4 \mathrm{~b}$ & $83.85 \mathrm{~b}$ & $24.59 \mathrm{~b}$ & $56.58 \mathrm{c}$ \\
$\mathrm{I}_{1}$ & $59.5 \mathrm{a}$ & $95.1 \mathrm{a}$ & $50.65 \mathrm{a}$ & $96.76 \mathrm{a}$ \\
$\mathrm{I}_{2}$ & $65.2 \mathrm{a}$ & $98.7 \mathrm{a}$ & $51.48 \mathrm{a}$ & $97.31 \mathrm{a}$ \\
$\mathrm{I}_{3}$ & $58.6 \mathrm{a}$ & $96.01 \mathrm{a}$ & $56.7 \mathrm{a}$ & $99.85 \mathrm{a}$ \\
$\mathrm{M}$ & $12.2 \mathrm{c}$ & $41.2 \mathrm{c}$ & $49.14 \mathrm{a}$ & $88.66 \mathrm{~b}$ \\
$\mathrm{LSD}$ at $0.05 \%$ & 10.30 & 8.12 & 8.36 & 6.07 \\
\hline
\end{tabular}

Different letters indicating significance at $\mathrm{P} \leq 0.05$; $\mathrm{C}$ : sole cow pea; $\mathrm{I}_{1}$ : alternate row intercrop; $\mathrm{I}_{2}$ : within row intercrop; $\mathrm{I}_{3}$ : mixed intercrop; M: sole maize

There is an increasing requirement that nutrient uptake and utilization by crop plants should be as efficient as possible. Greater nutrient uptake is usually presumed to be possible, because of some complementary exploration of the soil profile by intercrop components (Ahlawat et al., 1985) of fuller use of resources over time (Willey 1990). High total nutrient uptake in intercropping has been reported (Bulson et al., 1997; Choudhury and Rosario, 1994).

The weed dry weight was significantly affected by cropping systems (Tab. 3). The weed biomass in sole crop systems was significantly $(\mathrm{P}<0.05)$ greater than intercrop sys-

Tab. 3. Effect of different cropping system on dry weight of weed $\left(\mathrm{kg} \mathrm{ha}^{-1}\right)$

\begin{tabular}{lcccccc}
\hline $\begin{array}{c}\text { Cropping } \\
\text { system }\end{array}$ & $\mathrm{C}$ & $\mathrm{I}_{1}$ & $\mathrm{I}_{2}$ & $\mathrm{I}_{3}$ & $\mathrm{M}$ & $\begin{array}{c}\text { LSD at } \\
0.05 \%\end{array}$ \\
\hline $\begin{array}{l}\text { Weeds dry } \\
\text { weight }\end{array}$ & $106.23 \mathrm{~b}$ & $96.85 \mathrm{a}$ & $97.51 \mathrm{a}$ & $97.65 \mathrm{a}$ & $116.23 \mathrm{c}$ & 6.22 \\
\hline $\begin{array}{l}\text { C: sole cow pea; } \mathrm{I}_{1} \text { : alternate-row intercrop; } \mathrm{I}_{2} \text { : within row intercrop; } \mathrm{I}_{3}: \text { mixed } \\
\text { intercrop; M: sole maize }\end{array}$
\end{tabular}

tems. Weed dry weight showed no significant differences between different intercrop planting patterns (Tab. 3).

The morphological and physiological differences among intercrop components resulted in their ability to occupy different niches. Thus, environmental resources could be more efficiently utilized and converted to biomass by mixed stands of crops than by pure stands. Therefore, in the present experiment, more PAR interception and also greater water and nutrients extract (Tab. 1) by intercrops could be the major reason for the lower dry weight of weeds observed for intercropping over sole cropping. Lower weed biomass in intercropping has been reported by other authors (Eskandari and Ghanbari, 2010; Ghanrineh and Moosavi, 2010; Sobkowiz, 2006). Maereka et al. (2009) reported that inclusion of pumpkin in maize intercrops could be have had a synergetic effect on reducing the amount of resource consumption by weeds, resulting in lower weed density and weed biomass in maize-pumpkin intercrops compared to maize pure stands. Katsaruware and Manyanhaire (2009) concluded that maize-cowpea intercrops reduced weed biomass when compared to sole crops and it was as a result of limited availability of resources to weed species, where incoming PAR reaching the ground was reduced by maize-cowpea intercrop.

\section{Conclusions}

In general, it was concluded that environmental resource consumption, including PAR moisture and nutrients, in intercropping system was better than sole crops, suggesting that intercrop components have "complementarity effect" in environmental resource obtaining which is result of different morphological and physiological characteristics of intercrop components. More environmental resource consumption in intercropping resulted in lower weed biomass compared to sole crop systems.

\section{References}

Ahlawat IP, Singh A, Sharma RP (1985). Water and nitrogen management in wheat-lentil intercropping system under late-season condition. J Agric Sci 105:697-701.

Amanullah MM, Alagesan A, Vaiyapui K, Sathyamoorthi K, Pazhanivelan S (2006). Effect of intercropping and organic manures on weed control and performance of cassava (Manihot esculenta Cranz). J Agron 5(4):589-595.

Augustin B (2003). Urban areas-source of pesticide contamination of surface water? p. 166-169. In: Balder H, Strauch KH, Backhaus GF (Eds.). Second International Symposium on Plant Health in Urban Horticulture, Berlin, Germany.

Banik P, Midya A, Sarkar BK, Ghose SS (2006). Wheat and chickpea intercropping systems in an additive experiment. Advantages and weed smothering. Europ J Agron 24:325332. 
60

Bulson HA, Snaydon RW, Stopes CW (1997). Effect of plant density on intercropped wheat and field beans in an organic farming system. J Agric Sci 128:59-71.

Carruthers K, Fe Q, Cloutier D, Smith DL (1998). Intercropping corn with soybean, lupin and forages: Weed control by intercrops combined with inter row cultivation. Europ J Agron 8:225-238.

Chand SP (1997). Effect of time planting of traditional potato varieties on yield of intercropped potato and maize in the hills of Nepal. PhD thesis. Wye College, University of London.

Choudhury MK, Rosario EL (1994). Comparison of nitrogen, phosphorus and potassium utilization efficiency in maizemungbean intercropping. J Agric Sci 122:193-199.

Eskandari H, Ghanbari A (2010). Effect of Different Planting Pattern of Wheat (Triticum aestivum) and Bean (Vicia faba) on Grain Yield, Dry Matte Production and Weed Biomass. Notulae Scientia Biologicae 2(4):111-115.

Eskandari H, Ghanbari A (2009). Intercropping of maize and cowpea as whole-crop forage:effect of different planting pattern on total dry matter production and maize forage quality. Notulae Botanicae Horti Agrobotanici Cluj-Napoca $37(2): 152-155$.

Ghanbari-Bonjar A (2000). Intercropped wheat and bean as a low-input forage. PhD thesis. Wye College. Univ. London.

Gharineh MH, Moosavi SA (2010). Effects of intercropping (canola-fababean) on density and diversity of weeds. Notulae Scientia Biologicae 2(4):109-112.

Harris D, Natarajan M (1987). Physiological basis for yield advantage in a sorghum-groundnut intercrop exposed to drought. 2. Plant temperature, water status and components of yield. Field Crops Res 23:216-221.

Kadziuliene Z, Sarunaite L, Dereikyte I, Maiksteniene S, Arlauskiene A, Masilionyte L, Cenuleviciene R, Zekaite V (2009). Qualitative effects of pea and spring cereals intercrop in the organic farming systems. Agron Res 7(2):606-611.

Katsaruware RD, Manyanhaire IO (2009). Maize-cowpea intercropping and weed suppression in leaf stripped and detasselled maize in Zimbabwe. J Environ Agric Food Chemis 8(1):1218-1226.

Keating B, Carberry P (1993). Resource capture and use in intercropping:Solar radiation. Field Crops Res 34:273-301.

Kropff M (1993). General introduction, p. 1-8. In: Kropff M, Vanlaa H (Eds.). Modelling crop-weed interactions. CAB International, Walling ford, UK.
Liebman M, Dyck E (1993). Crop rotation and intercropping strategies for weed management. J Appl Ecol 3:92-122.

Maereka EK, Madakadze RM, Ngakanda C (2009). Productivity and weed suppression in maize-pumpkin intercrops in small scale farming communities of Zimbabwe. Afric J Crop Sci 9:93-102.

Mashingaizde AB, Nyakanda C, Chivinge OA, Washaireni AM, Dube KW (2000). Influence of a maize pumpkin live much on weed dynamics and maize yield. African Plant Protec 6(1):57-63.

Mashingaizdze AB (2004). Improving weed management and crop productivity in maize systems in Zimbabwe. $\mathrm{PhD}$ thesis. Wageningen University, Wageningen, Netherlands.

Midmore DJ, Raco J, Berrios D (1988). Potato in hot tropics. IV. Intercropping with maize and the influence of shade on potato micro-environment and crop growth. Field Crops Research 18:141-157.

Ofori F, Stern WR (1987). Cereal-legume intercropping systems. Adv Agron 41:41-90.

Oleszek K (1994). Brassicacea as alternative plants for weed control in sustainable agiculture. Fragm Agron 4(44):5-15.

Pandya N, Chouhau GS, Nepulia V (2005). Effect of vaieties, crop geometrics and weed management on nutrient uptake by soybean (Glycine max) and associated weeds. Indian J Agon 50(3):218-220.

Poggio SL (2005). Structure of weed communities occurring in monoculture and intercropping of field pea and barley. J Agric Ecosys Environ 109:48-58.

Snaydon RW (1991). Replacement and additive designs for competition studies. J Appl Ecol 28:934-946.

Sobkowiz P (2006). Comparison between triticale and field beans in additive intercrops. Plant Soil Environ 52:47-56.

Spliid NH, Carter A, Helweg A (2004). Non-agricultural use of pesticides-Environmental issues and alternatives. Pest Manage Sci 60:523.

Wanic M, Kostrzewska M, Jastrzebska M (2004). Role of intercrop sowing in weeds control for spring barley in cereal crops rotation. Fragm Agron 1(81):85-102.

Willey RW (1990). Resource use in intercropping systems. J Agric Water Manage 17:215-231. 